\title{
Patent Vs Trade Secret: Considering the Legal Protection of Covid-19 Vaccine in Indonesia Related to the State Intervention
}

\author{
Muh Ali Masnun* \\ Department of Law, Faculty of Social \\ Sciences and Law \\ Universitas Negeri Surabaya \\ Surabaya, Indonesia \\ alimasnun@unesa.ac.id
}

\author{
Eny Sulistyowati \\ Department of Law, Faculty of Social \\ Sciences and Law \\ Universitas Negeri Surabaya \\ Surabaya, Indonesia \\ enysulistyowati@unesa.ac.id
}

\author{
Hananto Widodo \\ Department of Law, Faculty of Social \\ Sciences and Law \\ Universitas Negeri Surabaya \\ Surabaya, Indonesia \\ hanantowidodo@unesa.ac.id
}

\begin{abstract}
The purpose of this study is to analyze how the legal protection of Covid-19 vaccine through an intellectual property rights protection approach. The protection is to weigh between patents and trade secrets by linking state intervention with the basis that the Covid-19 pandemic has become a global problem so there must be state interference in this matter. Research used normative juridical supported by both primary and secondary legal materials. The results of the study that the legal protection of Covid-19 can use patents or trade secrets. Patents and trade secrets as an IPR regime the inherent exclusive rights granted by the state, however, are unlimited. One form of limitation of exclusive patent rights is the rules regarding compulsory licenses, while limiting exclusive rights to trade secrets by allowing the disclosure of trade secrets on the grounds of public health and safety. State intervention in protecting the public of patent or trade secret exclusivity is by applying compulsory licenses to patents or disclosing information on trade secrets.
\end{abstract}

\section{Keywords: Patents, Trade Secrets, State Intervention}

\section{INTRODUCTION}

Corona Virus Disease 2019 (Covid-19) is one of the global problems experienced by all countries, including Indonesia. That is because the Covid-19 pandemic has a tremendous impact and affects various community activities in carrying out all its activities. The most visible impacts are in the economic sector including declining economic growth, employment in layoffs because the company stopped operating, even according to the International Monetary Fund (IMF) predicts that Covid-19 will cause a global recession that could be worse than the global financial crisis 2008 [1].

Efforts have been made by the government to overcome these problems by issuing policies to reduce the level of the spread of Covid-19, among others by implementing Large-Scale Social Restrictions (PSBB) and social distancing, even countries such as Italy have imposed a mass quarantine (lockdown). However, these efforts have not been too significant in reducing the spread rate of Covid-19.

Another effort that is no less important than the PSBB policy and social distancing is research to be able to find the Covid-19 vaccine. That until this article was compiled, the Covid-19 vaccine has not yet been found, so far it is still being developed to the stage of clinical trials, so many scientists from several countries are competing to find the vaccine, because the vaccine is one of the most effective ways to reduce the spread and treat Covid-19.

Covid-19 vaccine according to the author's view is one thing that is needed for everyone so for the inventors of their efforts feel the need to protect it, so that people or other parties who will use or produce need an inventor's permission. Finally, inventors can obtain economic benefits for their inventions.

Protection of the Covid-19 vaccine can be carried out using the Intellectual Property Rights (IPR) protection approach. IPR is an exclusive right granted by the state to an inventor, creator or designer for the inventions, creations or designs they produce, so that they have full rights to prohibit others from using or producing. The IPR regime that can protect Covid-19 is Patent or Trade Secret.

The purpose of this study is to analyze how the protection of Covid-19 vaccines associated with the state intervention. Why is there interference from the state, because in the writer's view that the Covid-19 pandemic is one of the responsibilities of the state in dealing with this. Finally, state interference is a form of limitation of exclusive rights over IPR.

\section{RESEARCH METHODS}

Author uses normative juridical research, namely legal research which bases its analysis on applicable laws and regulations and is relevant to the legal issues that are the focus of research [2]. This research uses literature study (secondary data) in the form of primary and secondary legal 
materials. Primary legal material in the form of regulations related to Law Number 13 Year 2016 concerning Patents, Law Number 30 Year 2000 concerning Trade Secrets. Secondary legal materials are used to support primary legal materials from books and journals that are relevant to the problem. The approach used in this research is a statute approach, which is then analyzed and formulated a conclusion and suggestion.

\section{RESULT AND DISCUSSION}

Humans are blessed by God Almighty in the form of thought, and could be optimized by producing a work that has creativity in the form of creation, design, and invention in the fields of science and technology. Intellectual output is usually familiar with intellectual property, which if intellectual property has had the protection provided by the state will become Intellectual Property Rights [3].

Intellectual property protection is known by two systems, first that intellectual property protection through registration first, this system is known as a constitutive system (first to file system) that is applied to IPRs in the industrial sector including patents, brands, industrial designs. Second, that the automatic protection of intellectual property (automatic protection) when the work has been realized, this system is commonly known as a declarative system that is closer to copyright and related rights.

Covid-19 vaccine according to the author is an intellectual property that can obtain protection with the concept of IPR, although until now the vaccine has not been found, the authors have confidence that soon the vaccine will definitely be found. Therefore, the author feels the need to protect the vaccine.

The IPR regime that can protect the Covid-19 Vaccine according to the author's perspective is Patent or Trade Secret, of course this must be proven by analyzing the fulfillment of the substantive conditions of each of these regimes. Protection either using patents or trade secrets each has advantages and disadvantages, so the inventor needs to think carefully which regime will be chosen. More detailed each will be reviewed in the section below.

\section{A. THE PROTECTION OF COVID-19 THROUGH PATENS}

Patents as one type of IPR are exclusive rights granted to inventors in the technology both products and processes. The patent terminology itself is a development of the Dutch language term Octrooi, while the word is from the Latin word auctor / auctorizare which means opened. The meaning of the word opened can be interpreted as an invention that has been discovered and then opened and known by the general public. The implication of the opening is that other parties who want to use must authorize the inventor as a form of reward in addition to increasing the enthusiasm of inventions in other technology fields.
IPR patents in the technology sector have a very important role in terms of development in Indonesia, especially in terms of stimulating economic growth through 4 (four) mechanisms as disclosed by Rindia Fanny, among others:

1. Technology transfer and investment of patent information in the patent description;

2. Research and development in universities and research institutions;

3. Catalysts for new technology and business;

4. Businesses collect and use patents in the context of granting joint business licenses and other profitable transactions.

Referring to the idea, according to the author's view, patent is one of the development milestones for a country, especially Indonesia as a developing country that needs to accelerate so that it can catch up with developed countries through providing patent protection for inventors. Patent protection is based on justification as revealed by Endang Purwaningsih, Incentive to create invention, which is an incentive for research and development, rewarding, and patent activities as a source of information, meaning that there is a disclosure clause [4]. Patents are not granted for all inventions, but an invention must have certain substantive requirements, novelty, can be industrial applicability), has an inventive step and also meet formal requirements [5].

The Covid-19 vaccine inventor if he chooses to be protected through a patent regime, the most important thing is to fulfill the substantive requirements. Covid-19 vaccine if analyzed clearly meets the novelty, because Covid-19 is a relatively new disease and the vaccine has not been found. Therefore, when the vaccine was discovered, the authors had the notion that the vaccine invention was not the same as the technology that had been revealed previously.

The second substantive requirement is that it can be applied in the industrial world, that the Covid-19 vaccine as a vaccine in general where the vaccine can be produced on a large scale to meet the needs. The third contains an inventive step can be interpreted that for a virus expert is something that was not previously thought. Based on this, in the view of the author has met the substantive requirements, so that it can be protected through the patent regime.

Other considerations, that patent protection has weaknesses, among others include that the process of patent protection requires a relatively long time until an invention is granted, patent registration fees and annual fees are one thing that should be considered by the inventor, limited protection period of twenty (20) years and cannot be extended, and the invention is known publicly which is a consequence of disclosure clauses.

\section{B. THE PROTECTION OF COVID-19 VACCINE THROUGH TRADE SECRET}

Trade secrets are one of the IPR regimes in the form of exclusive rights granted by the state to information that is 
not publicly known in the field of technology or business, has economic value, and the information is kept confidential. That as long as the author observes that trade secrets are one of the IPR regimes that are not as familiar as other regimes such as copyright, patent, or trademark. This is based on the limitations of books, journals, or cases in court when compared to other IPR regimes as mentioned above. However, in the view of the author, trade secrets are a viable and worthy choice to protect information in the technology or business fields. This trade information needs to be protected because it:

a. is morally rewarding for those who find it;

b. materially provide insentive [6].

Substantive conditions for trade secrets to be protected as regulated in the Trade Secrets Act include: information is confidential, the information has economic value, and there are efforts to protect that information. Covid-19 vaccine is a formula that has been discovered by a virologist, if in the end the inventor feels the need to protect because of its economic value, it is certain that the formula information for the vaccine will be kept confidential and only very limited parties are allowed to know this.

Information on the Covid-19 vaccine formula certainly has economic value, it is based that currently almost all countries need the Covid-19 vaccine to overcome the global pandemic. Inventors can sell the vaccine at a price that is expensive or comparable to the effort / effort they make. Inventors certainly do not just remain silent on information that has economic value, but they must certainly make efforts to safeguard information on the Covid-19 vaccine formula, among others by binding through work agreements that contain the provisions.

The advantage of Covid-19 vaccine protection is that the period of protection is unlimited as long as the confidential information is maintained. That the protection of trade secrets is not like a patent which requires a long and relatively large amount of time and cost. The disadvantage of protection through trade secrets is that at any time if there are other parties who obtain technology (Covid-19 vaccine formula) withheld, but the acquisition is in good faith (research, trial and error) then the protection of trade secrets cannot prevent the other party (exclusive rights do not apply). It did not even rule out the possibility of protecting it through a patent regime.

Covid-19 protection as previously reviewed is possible through patents or trade secrets. Inventor must determine which regime to use, because protection by using both regimes according to the author's view is not possible. That when the choice is protected through patents, there will be disclosure clauses which means the information is no longer confidential. Likewise, if protected through trade secrets, the vaccine formula information is only known by very limited parties, so it certainly does not meet the patent protection.

\section{THE STATE INTERVENTION}

Implication of the exclusive right to an IPR is that the inventor can use fully prohibit other people in terms of making, using, selling, importing, renting, handing, or providing for sale or leasing or handing over. The exclusive rights referred to are not without limits, but there are still limitations, especially that all countries need the Covid-19 vaccine to overcome this global pandemic. Therefore, the state needs to be present through interventions related to this matter to limit the exclusivity of IPR.

Limiting exclusive rights is not without reason, although in principle there is a justification related to the inherent wealth of those who produce the work. That exclusive exploitation of IPR can cause social injustice, especially in matters of public interest. Therefore, there is a mechanism for transferring IPRs as mentioned previously, the one mentioned is a written agreement. Analysis of state interventions in patents and trade secrets will be reviewed below.

The transfer of IPR is still possible with the mechanism of inheritance, grants, wills, endowments, or written agreements. One form of a written agreement that is used in patent application is license. License means a form of the right to take one or a series of actions or actions given by those authorized in the form of a permit. Without this permit, the action or action is an illegal prohibited act which is an act against the [7]. According to Gunawan Widjaja, a license is a form of granting a license to utilize an intellectual property right that can be granted by the licensor to the licensee so that the recipient can carry out a form of business activity, both in the form of technology or knowhow that can be used to produce result in selling or marketing certain (tangible) goods or those which will be used to carry out certain service activities using the licensed IPR [8].

Licenses are generally classified into two types namely general licenses and forced licenses or commonly known as the compulsory licenses, non-voluntary licenses, other uses without the authorization of the right holder [9]. General licenses can still be divided into two, namely exclusive and non-exclusive licensing agreements. An exclusive license can be interpreted as an agreement that merely adds further promise from the licensor not to enter into similar agreements with other parties. Non-exclusive licenses can be interpreted that the licensee has no rights to third parties and the licensor cannot circumvent the sublicensing agreement, so that the licensor can freely enter into a licensing agreement with another party.

Licenses in patents are known by the two licenses (see Patent Law), compulsory licenses can be interpreted as permission to be able to carry out patents for certain reasons given by the government as will be the author of a review related to patents on the Covid-19 vaccine. Based on Law Number 13 Year 2016 regarding Patents (hereinafter referred to as Patent Law) Article 81 states that a compulsory license is a form of a non-exclusive compulsory license [10]. 
Article 7 TRIPs provisions and by observing Paragraph 4 of the Preamble TRIPs, the balance between rights and obligations cannot be obtained through reducing the rights of patent holders without adding to the collective interest of the wider community [11]. This means that the individual rights of the patent holder must not be reduced for the benefit of other individuals, only social and collective interests can justify the imposition of a compulsory license. Compulsory licensing can be granted to two categories of applicants namely the Government (or Government bodies or third parties authorized by the state) and other private third parties [12]. The application of compulsory licenses by either the government or third parties cannot be granted, but must be with special reasons, including:

a. To prevent the abuse of patent holder rights resulting from the exercise of other exclusive rights (Article 5A (2) and (3) Paris Convention) [13];

b. To reduce the absence or inadequate implementation of patented inventions (Article 5A (2) and (3) Paris Convention);

c. For the benefit of the community, among others, in accordance with the urgent needs of a country or other extreme situations and conditions or the interests of the community not for commercial use (Article 31 (b) TRIPs);

d. To anticipate if the Patent Holder or Licensee receives a Patent in a form and manner that is detrimental to the interests of the community (Article 82 paragraph (1) of the Patent Law);

e. To produce pharmaceutical products that have been granted a Patent in Indonesia for the treatment of diseases in humans (Article 93 paragraph (1) of the Patent Law);

f. For imports of pharmaceutical product procurement that have been granted a Patent in Indonesia but cannot be produced in Indonesia for the treatment of diseases in humans (Article 93 paragraph (2) of the Patent Law); or

g. To export pharmaceutical products that have been patented and produced in Indonesia for the treatment of diseases in humans based on requests from developing or undeveloped countries (Article 93 paragraph (2) of the Patent Law).

The reasons as mentioned above, certainly can be used as material for the urgency of the application of a compulsory license if it will be applied to a Covid-19 patent license. State intervention in such matters as this is no longer negotiable to realize the objectives of the country, especially as a compulsory license applicant if Indonesia is the licensee. This is in line with Article 8 TRIPs which states that member countries can set or change their laws and regulations to determine the size of protection needed for public health. In addition, compulsory licensing in the field of drug patents (in this context is the Covid-19 vaccine) also provides easier access to medicines originating from developed countries and the price of vaccines is more affordable [14]. The application of compulsory patent licensing is very important, it is based on conflicts of interest, especially political and economic interests. This has resulted in disharmony in the administration of public policy in general and compulsory patent licensing in particular, which often sacrifices the interests of the wider community.

Trade Secrets as stipulated in the Trade Secrets Act do not recognize compulsory licenses as in patents, so the application of compulsory licenses is not possible. The principle of a licensing agreement in trade secrets is not contrary to the interests of the Indonesian economy and is prohibited from containing the provisions of restrictions that hamper the ability of the Indonesian people to master and develop technology. The principle as intended to stimulate economic growth in Indonesia in the sense of improving the standard of living and quality of life of the people of Indonesia [15].

Finally, if the inventor prefers to protect the Covid19 vaccine, then Article 15 of the Trade Secret Law has accommodated the disclosure of trade secrets on the grounds of defense and security, health, or public safety, and that can be categorized as not including a violation of trade secrets. Public health and safety reasons from the author's perspective can be used as a basis for justification that the state can intervene through the disclosure of the Covid-19 vaccine trade secret.

\section{CONCLUSION}

The protection of Covid-19 vaccine in the IPR regime can use patents or trade secrets with their respective strengths and weaknesses. That the choice between the two goes back to the inventor to choose which regime. Patents and trade secrets as an IPR regime adhere to the exclusive rights granted by the state, however they are not unlimited. One form of limitation of exclusive patent rights is the rules regarding compulsory licenses. Compulsory licensing for Covid-19 patents has been permitted under the Paris Convention, TRIPs, or Patent Law. The reason for the importance of a Covid-19 patent compulsory license is to prevent the misuse of patent holder rights that harm the community, meet the immediate needs of a country or other extreme situations and conditions or the interests of the community (in this case for the benefit of public health). Limitation of exclusive trade secret rights by allowing the disclosure of trade secrets for reasons of public health and safety. State intervention in protecting the public of patent or trade secret exclusivity is by applying compulsory licenses to patents or disclosing information on trade secrets.

\section{REFERENCES}

[1] N. T. S. Saptadi, "Dampak Corona bagi Perekonomian Indonesia," OPINI, Makassar Tribun News, 2020. [Online]. Available: https://makassar.tribunnews.com/2020/03/28/dampak -corona-bagi-perekonomian-indonesia.

[2] K. Benuf and M. Azhar, "Metodologi Penelitian 
Hukum Sebagai Instrumen Mengurai Permasalahan Hukum Kontemporer," J. Gema Keadilan, vol. 7, no. 1, p. 24, 2020.

[3] M. A. Masnun and D. Roszana, "Persoalan Pengaturan Kewajiban Pemegang Paten untuk Membuat Produk atau Menggunakan Proses di Indonesia," J. IUS Quia Iustum, vol. 26, no. 2, p. 327, 2019.

[4] E. Purwaningsih, Perkembangan Hukum Intellectual Property Rights. Jakarta: PT. Ghalia Indonesia, 2005.

[5] A. K. Muhammad, Hukum Ekonomi Hukum Kekayaan Intelektual. Bandung: PT. Citra Aditya Bakti, 2001.

[6] S. Mahila, "Perlindungan Rahasia Dagang Dalam Hubungannya Dengan Perjanjian Kerja," J. Ilm. Univ. Batanghari Jambi, vol. 10, no. 3, p. 18, 2010.

[7] T. Hanoraga and N. Prasetyawati, "Lisensi Wajib Paten Sebagai Salah Satu Wujud Pembatasan Hak Ekslusif Paten," J. Sos. Hum., vol. 8, no. 2, p. 160, 2015.

[8] G. Widjaja, Seri Hukum Bisnis Lisensi. Jakarta: PT. Raja Grafindo Persada, 2003.
[9] R. Gumanti, "Perjanjian Lisensi di Indonesia," J. AlMizan, vol. 12, no. 1, p. 255, 2016.

[10] Kementrian Sekretariat Negara Republik Indonesia, Undang-Undang Nomor 13 Tahun 2016 Tentang Paten. Jakarta, 2016.

[11] Trade Related Aspects of Intellectual Property Rights (TRIPs) Agreement.

[12] C. C. Priapantja, Hak Kekayaan Intelektual: Tantangan Masa Depan. Jakarta: Badan Penerbit Fakultas Hukum Universitas Indonesia, 2003.

[13] Paris Convention for the Protection of Industrial Property.

[14] Ni. S. Dewi and Suteki, "Obstruksi Pelaksanaan Lisensi Wajib Paten dalam Rangka Alih Teknologi pada Perusahaan Farmasi di Indonesia," J. Law Reform, vol. 13, no. 1, p. 2, 2017.

[15] R. S. Chandrika, "Perlindungan Hukum Perjanjian Lisensi Rahasia Dagang di Indonesia," J. Bonum Commune Bus. Law, vol. 2, no. 1, p. 16, 2019. 